\title{
The fibrinogen-binding protein (FgBP) of Streptococcus equi subsp. equi additionally binds IgG and contributes to virulence in a mouse model
}

\author{
Mary Meehan, ${ }^{1,2}$ Yvonne Lynagh, ${ }^{1}$ Caroline Woods ${ }^{3}$ and Peter Owen ${ }^{1}$
}

Author for correspondence: Peter Owen. Tel: +353 1 6081188. Fax: +35316799294.

e-mail: powen@tcd.ie

Department of Microbiology, Moyne Institute of Preventive Medicine1, National Pharmaceutical Biotechnology Centre, BioResearch Ireland ${ }^{2}$ and Bioresources Unit3, Trinity College, Dublin 2, Ireland

\begin{abstract}
The major cell-wall-associated protein of the equine pathogen Streptococcus equi subsp. equi is an M-like fibrinogen-binding protein (FgBP) which binds equine fibrinogen $(\mathrm{Fg})$ avidly, through residues located at the extreme $\mathrm{N}$ terminus of the molecule. In this study, it is shown that FgBP additionally binds equine IgG-Fc. When tested against polyclonal IgG from ten other animal species, it was found that FgBP binds human, rabbit, pig and cat IgG, but does not bind mouse, rat, goat, sheep, cow or chicken IgG. Through the use of a panel of recombinant FgBP truncates containing defined deletions of sequence, it was shown that residues in the central regions of FgBP are important in IgG binding. An fbp knockout mutant which does not express FgBP on the cell surface was also constructed. Mutant cells failed to autoaggregate, bound no detectable equine Fg or IgG-Fc, were rapidly killed in horse blood, and showed greatly decreased virulence in a mouse model. Results suggest that FgBP is the major surface structure responsible for binding either Fg or IgG, that the molecule has pronounced antiphagocytic properties, and that it is a likely factor contributing to the virulence of wild-type $S$. equi subsp. equi.
\end{abstract}

Keywords: IgG-binding protein, phagocytosis, autoaggregation, ligand-binding domains, strangles

\section{INTRODUCTION}

Lancefield group A, C and G streptococci express on their cell surface a group of fibrous proteins, termed $M$ or M-like proteins, which form $\alpha$-helical coiled-coil dimers and which bind host serum or matrix proteins such as fibrinogen $(\mathrm{Fg})$, immunoglobulins, albumin, kininogen and plasminogen (reviewed by Navarre \& Schneewind, 1999). One or more of these proteins can be expressed by individual bacterial strains. In the case of the group A streptococci there are $>80$ serotypes of $\mathrm{M}$ proteins, and these have been shown to be major virulence determinants and protective antigens. Although the precise mechanism by which $\mathrm{M}$ proteins contribute to virulence is unclear, there is evidence to suggest that $M$ proteins can be involved in adhesion, invasion and evasion of the host defences. Indeed, the

Abbreviations: Em, erythromycin; Fg, fibrinogen; FgBP, fibrinogenbinding protein; HRP, horseradish peroxidase; i.p., intraperitoneal(ly); Km, kanamycin. major functional characteristic of these proteins is their ability to confer on streptococci the capacity to resist phagocytosis in whole blood in the absence of specific antibody. This has variously been attributed to: (i) a reduction in deposition of complement $\mathrm{C} 3 \mathrm{~b}$ on the streptococcal cell surface due to binding by $\mathrm{M}$ proteins of fibrinogen and/or complement regulators, e.g. factor $\mathrm{H}$, factor $\mathrm{H}$-like protein and $\mathrm{C} 4 \mathrm{~b}$-binding protein; (ii) the promotion of large bacterial aggregates which are more difficult to phagocytose; and (iii) the ability of Fg to compete with streptococcal-associated C3bi binding to CD11b-CD18-expressing cells and prevent phagocytosis (Frick et al., 2000; Kehoe, 1994; Navarre \& Schneewind, 1999; Ringdahl et al., 2000).

The Lancefield group C streptococcus Streptococcus equi subsp. equi is the causative agent of strangles, which is a highly contagious disease of the upper respiratory tract of the family Equidae and one of the most frequently reported equine diseases world-wide. The disease is initially characterized by nasal discharge and fever, followed by abscess formation in local lymph 
nodes. Morbidity rates of up to $100 \%$ have been reported, and in up to $10 \%$ of cases mortality can occur as a result of disseminated abscessation (bastard strangles; Timoney, 1993).

S. equi has the potential to express at least five wallassociated proteins, viz. two fibronectin-binding proteins (FNE and SFS; Lindmark \& Guss, 1999; Lindmark et al., 2001), an $\alpha_{2}$-macroglobulin/albumin/IgG-binding protein (ZAG; Lindmark et al., 1999) and two Fgbinding proteins termed FgBP or SeM and SzPse (Meehan et al., 1998; Timoney et al., 1997). Of these, $\mathrm{FgBP}$ is by far the most dominant wall-associated protein expressed by virulent S. equi (Meehan et al., 1998). FgBP is a highly immunogenic protein that behaves as a multimer $(220000 \mathrm{Da})$ during SDS-PAGE, reacts with convalescent horse serum, and is protective in a small animal model against lethal $S$. equi challenge. The sequence of the corresponding gene $(f b p)$ has been determined and shown to encode a protein of 534 amino acids $(58344 \mathrm{Da})$, which possesses some structural and sequence similarities to other streptococcal cell wall proteins. Based on experimentation and computer predictions, these have been shown to include a 36-residue signal sequence, a cell wall/membrane anchoring domain and two blocks (A and $\mathrm{B}$ ) of degenerate repeated sequences (Meehan et al., 1998, 2000a). In addition, computer-assisted secondary structure analysis predicts that $\mathrm{FgBP}$, like $\mathrm{M}$ proteins, possesses a high proportion (over $60 \%$ ) of $\alpha$-helical coiled-coil (dimer) structure (Meehan et al., 1998). However, the protein shows little significant sequence similarity to other $\mathrm{M}$ (-like) proteins, except for the $\mathrm{Fg} / \mathrm{IgG}$-binding DemA protein from Streptococcus dysgalactiae, where some similarities in the A-repeat and C-terminal regions have been noted (Vasi et al., 2000).

The region within FgBP required for maximum binding of Fg has been located, using a panel of 20 recombinant hexahistidyl $\left(\mathrm{His}_{6}\right)$-tagged $\mathrm{FgBP}$ truncates possessing overlapping $\mathrm{N}$ - and C-terminal deletions of sequence (FgBP1-17) and specific internal deletions of the $\mathrm{A}$ repeat and/or $\mathrm{B}$ repeats $\left(\mathrm{FgBP}\left[\mathrm{A}^{-}\right], \operatorname{FgBP}\left[\mathrm{B}^{-}\right]\right.$and $\left.\mathrm{FgBP}\left[\mathrm{A}^{-} \mathrm{B}^{-}\right]\right)$. This has been shown to extend over a large aspect (the $\mathrm{N}$-terminal half) of the mature protein. Maximum ligand binding is not dependent on the presence of the A and/or B repeats, but is critically dependent on residues within the first $19 \mathrm{~N}$-terminal amino acids and also on an extended region of (stabilizing) coiled-coil structure (Meehan et al., 1998, 2000a, b). This contrasts with the situation for M1 and M5 proteins of group A streptococci where the centrally located B repeats appear to be critical for Fg binding (Ringdahl et al., 2000).

Previous studies have shown that $S$. equi cells are resistant to non-immune phagocytosis, and there is some indirect evidence that $\mathrm{FgBP}$ may be involved (Boschwitz \& Timoney, 1994a, b; Chanter et al., 1994). Thus, Timoney and co-workers showed that an isolate of $S$. equi expressing high levels of $M$ protein (very likely $\mathrm{FgBP}$ ) bound four times more complement $\mathrm{C} 3 \mathrm{~b}$ and survived 100-fold better than an unrelated isolate which apparently expressed lower levels of the antigen. In addition, specific antiserum inhibited survival of $S$. equi in whole blood, whereas the presence of fibrinogen enhanced the ability of $S$. equi to resist killing by equine neutrophils (Boschwitz \& Timoney, 1994a, b; Chanter et al., 1994).

In this paper we show for the first time that FgBP binds IgG as well as Fg. In addition, we describe the construction of an $f b p$ insertion mutant of $S$. equi subsp. equi and demonstrate convincingly that FgBP plays a role in resistance to phagocytosis, and in virulence.

\section{METHODS}

Bacterial strains, plasmids and growth conditions. The bacterial strains and plasmids used in this study are detailed in Table 1. Strains of S. equi were grown at 30,37 or $39^{\circ} \mathrm{C}$ as appropriate on Columbia base agar supplemented with $5 \%$ (v/v) horse blood, on Todd-Hewitt agar supplemented with $0 \cdot 2 \%(\mathrm{w} / \mathrm{v})$ yeast extract (THYE agar), or statically overnight $(15 \mathrm{~h})$ in THYE broth supplemented where appropriate with kanamycin $\left(\mathrm{Km} ; 200 \mu \mathrm{g} \mathrm{ml}^{-1}\right)$ and erythromycin (Em; $1.5 \mu \mathrm{g} \mathrm{ml}^{-1}$ ). For autoaggregation experiments, cells were grown to stationary phase $(20-24 \mathrm{~h})$. Escherichia coli strains were grown at $37^{\circ} \mathrm{C}$ in L-broth (Sambrook et al., 1989) medium or in $2 \times$ YT medium (Lech \& Brent, 1997) supplemented, where appropriate, with ampicillin $\left(100 \mu \mathrm{g} \mathrm{ml}^{-1}\right)$, chloramphenicol $\left(25 \mu \mathrm{g} \mathrm{ml}^{-1}\right)$, tetracycline $\left(10 \mu \mathrm{g} \mathrm{ml}^{-1}\right), \mathrm{Km}\left(25 \mu \mathrm{g} \mathrm{ml}^{-1}\right), \mathrm{Em}\left(400 \mu \mathrm{g} \mathrm{ml}^{-1}\right)$ and IPTG (1 mM).

Recombinant DNA techniques. Genomic DNA was isolated from S. equi TW by a modification (Meehan et al., 1998) of the method of Yu \& Ferretti (1989). Plasmid DNA was purified from $E$. coli by the modified alkaline lysis method of Feliciello \& Chinali (1993), or with a plasmid purification kit (Qiagen). DNA digestions, ligations, transformations and electroporations were carried out by standard methods (Caparon \& Scott, 1991; Sambrook et al.,1989). Southern hybridizations of genomic DNA, digested with SacI and NdeI, were carried out at $65^{\circ} \mathrm{C}$ in standard hybridization buffer (Boehringer Mannheim). Probes (fragments of $f b p, \mathrm{pG}+$ host 9 and $\Omega \mathrm{Km} 2$ ) were labelled with digoxigenin by random priming, as described by the manufacturer (Boehringer Mannheim). Forward (F1， 5'-CCGGAATTCGGTCCTTATCAAATACTG3'; F2, 5'-GACCAAGCTTAGACCGCTTGGTAGAGTCTGC- $\left.3^{\prime}\right)$ and reverse (R1, 5'-GACCAAGCTTCTGCAAGTTTAGCCTCAAGAAG-3'; R2, 5'-GAGCACGGGCCC

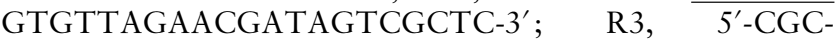
GGATCCGCGCAGAAAACCATTAGCC-3') oligonucleotide primers (Sigma-Genosys) complementary to selected $f b p$ sequence and to sequence regions upstream and downstream of $f b p$ and containing, where appropriate, engineered restriction endonuclease cleavage sites (underlined), were used to amplify $f b p$ fragments. Amplified fragments were gelpurified using the Wizard PCR Preps DNA purification kit (Promega).

Construction of $S$. equi fbp mutants. An insertion mutation in the $f b p$ gene was constructed by replacement of the central 407 bp of the $f b p$ sequence with the $\Omega \mathrm{Km} 2$ interposon (Fig. 1b; Perez-Casal et al., 1991; Prentki \& Krisch, 1984), and involved using the broad-host-range thermosensitive plasmid $\mathrm{pG}+$ host9 to mutagenize the wild-type chromosomal copy of $f b p$ via a double-crossover integration event. pG+host9 
Table 1. Bacterial strains and plasmids used in the study

\begin{tabular}{|c|c|c|}
\hline Strain or plasmid & Relevant genotype or property & Source \\
\hline \multicolumn{3}{|l|}{ Strains } \\
\hline S. equi TW & Virulent isolate from a case of strangles & $\begin{array}{l}\text { Meehan et al. } \\
\text { (1998) }\end{array}$ \\
\hline S. equi fbp:: $\Omega \mathrm{Km} 2$ & S. equi TW fbp::sKm2; $\mathrm{Km}^{\mathrm{r}} \mathrm{Em}^{\mathrm{s}}$ & This study \\
\hline S. equi fbp:: $\Omega \mathrm{Km} 2(\mathrm{pFBP} 4)$ & Complemented derivative of $S$. equi fbp:: $\Omega \mathrm{Km} 2 ; \mathrm{Km}^{\mathrm{r}} \mathrm{Em}^{\mathrm{r}} \mathrm{Cm}^{\mathrm{s}}$ & This study \\
\hline E. coli XL-1 Blue & $\begin{array}{l}\text { recA1 endA1 gyrA96 thi-1 hsdR17 supE44 relA1 lac }\left(\mathrm{F}^{\prime} \text { pro } A B \text { lacl }^{\mathrm{a}} \mathrm{Z} \Delta \mathrm{M} 15\right. \\
\mathrm{Tn} 10) ; \mathrm{Tc}^{\mathrm{r}} \text {; used to propagate pBluescript and } \mathrm{pQE} 30\end{array}$ & Stratagene \\
\hline E. coli $\mathrm{T} 61$ & $r e p^{+} \operatorname{rec} A(\mathrm{pGK} 12) ; \mathrm{Km}^{\mathrm{r}}, \mathrm{Tc}^{\mathrm{r}} ;$ used to propagate $\mathrm{pG}+$ host 9 & E. Maguin* \\
\hline \multicolumn{3}{|l|}{ Plasmids } \\
\hline pFBP1 & $\begin{array}{l}1584 \text { bp ligated PCR fragment carrying } \Delta f b p 461-866 \text { with an internal HindIII site } \\
\text { in pBluescript II SK }(+) ; A p^{r}\end{array}$ & This study \\
\hline pFBP2 & 2200 bp $\Omega K \mathrm{~m} 2$ interposon inserted into HindIII-digested pFPB1; $\mathrm{Ap}^{\mathrm{r}} \mathrm{Km}^{\mathrm{r}}$ & This study \\
\hline pFBP3 & $3784 \mathrm{bp} f b p:: \Omega \mathrm{Km} 2$ fragment in EcoRI-ApaI-digested pG +host9; $\mathrm{Em}^{\mathrm{r}} \mathrm{Km}^{\mathrm{r}}$ & This study \\
\hline pFBP4 & 2063 bp PCR fragment encompassing the complete $f b p$ gene in pVA838; $\mathrm{Em}^{\mathrm{r}} \mathrm{Cm}^{\mathrm{s}}$ & This study \\
\hline pBluescript II SK $(+)$ & ColE1 oriV lacZ $\alpha$ phagemid cloning vector; $\mathrm{Ap}^{\mathrm{r}}$ & Stratagene \\
\hline pG + host 9 & Thermosensitive broad-range cloning vector; $\mathrm{Em}^{\mathrm{r}}$ & $\begin{array}{l}\text { Maguin et al. } \\
\text { (1996) }\end{array}$ \\
\hline 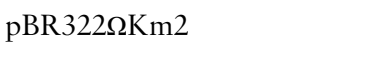 & pBR322 containing the $\Omega \mathrm{Km} 2$ interposon; $\mathrm{Km}^{\mathrm{r}} \mathrm{Tc}^{\mathrm{r}}$ & $\begin{array}{l}\text { Perez-Casal et al. } \\
\text { (1991) }\end{array}$ \\
\hline pVA838 & E. coli-streptococcal shuttle plasmid; $\mathrm{Em}^{\mathrm{r}} \mathrm{Cm}^{\mathrm{r}}$ & $\begin{array}{l}\text { Macrina et al. } \\
\text { (1982) }\end{array}$ \\
\hline pQE30 & Cloning and expression vector to produce $\mathrm{N}$-terminal $\mathrm{His}_{6}$-tagged proteins; $\mathrm{Ap}^{\mathrm{r}}$ & Qiagen \\
\hline
\end{tabular}

*E. Maguin, Laboratoire de Genetique Microbienne, Institut National de la Recherche Agronomique, Jouy en Josas, France.

cannot replicate at temperatures above $35^{\circ} \mathrm{C}$ (Maguin et al., 1996). Primers F1 and R1 were used to amplify a DNA fragment corresponding to the first $460 \mathrm{bp}$ of $\mathrm{fbp}$ (encoding amino acids 1-153 of unprocessed FgBP) together with $323 \mathrm{bp}$ of upstream sequence; primers $\mathrm{F} 2$ and R2 were used to amplify a DNA fragment corresponding to the final 739 bp of $f b p$ (encoding amino acids 290-534 of unprocessed FgBP) plus 62 bp of downstream sequence. One hundred microlitre PCR reactions were performed in $p f u$ polymerase buffer (Promega) containing $3 \mathrm{U} p f u$ polymerase, $250 \mathrm{ng}$ of forward and reverse primers, $250 \mu \mathrm{M}$ dNTPs and $500 \mathrm{ng} S$. equi genomic DNA. Amplification conditions consisted of 30 cycles of denaturation at $94{ }^{\circ} \mathrm{C}$ for $1 \mathrm{~min}$, annealing at $55^{\circ} \mathrm{C}$ for $1 \mathrm{~min}$ and extension at $72{ }^{\circ} \mathrm{C}$ for $2.5 \mathrm{~min}$, followed by a final extension at $72{ }^{\circ} \mathrm{C}$ for $10 \mathrm{~min}$. Gel-purified PCR fragments were cleaved as appropriate with EcoRI, HindIII and ApaI. The cleaved products were then ligated and cloned into pBluescript cleaved with EcoRI and ApaI, to generate the plasmid pFBP1. pFBP1 was then cleaved with HindIII, filled in with DNA polymerase I large (Klenow) fragment, and ligated with the

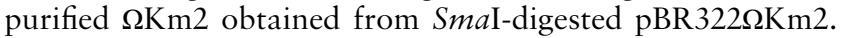
The resultant plasmid (pFBP2) was cut with EcoRI and ApaI, and the 3784 bp $f b p:: \Omega K m 2$ DNA fragment (Fig. 1b) was gelpurified and then ligated to plasmid $\mathrm{pG}+$ host $9\left(\mathrm{Em}^{\mathrm{r}}\right)$ digested with EcoRI and ApaI. The resultant plasmid (pFBP3) was purified, electroporated into $S$. equi TW, and $\mathrm{Km}^{\mathrm{r}} \mathrm{Em}^{\mathrm{r}}$ transformants were grown at $30^{\circ} \mathrm{C}$ in order to select derivatives carrying the replicating plasmid. A double-crossover event between homologous sequences on pFBP3 and the $S$. equi chromosome was facilitated by a temperature shift to $39^{\circ} \mathrm{C}$, resulting in the loss of $\mathrm{pG}+$ host9, integration of $\Omega \mathrm{Km} 2$ into chromosomal $f b p$ and a $\mathrm{Km}^{\mathrm{r}} \mathrm{Em}^{\mathrm{s}}$ phenotype. For this procedure, an overnight culture of $S$. equi TW(pFBP3) grown at $30^{\circ} \mathrm{C}$ was diluted $1: 100$ into fresh THYE broth, grown for
$24 \mathrm{~h}$ at $39^{\circ} \mathrm{C}$ (subculturing once after $7 \mathrm{~h}$ ), and finally plated onto THYE agar containing $\mathrm{Km}$. Out of $150 \mathrm{Km}^{\mathrm{r}}$ transformants of $S$. equi, six were found to be $\mathrm{Km}^{\mathrm{r}} \mathrm{Em}^{\mathrm{s}}$. PCR experiments using several primer sets covering different regions of $f b p$ and Southern hybridization of restriction enzyme digested genomic DNA using probes specific for $f b p$, $\mathrm{pG}+$ host 9 and the $\Omega \mathrm{Km} 2$ element confirmed that these six transformants did not possess $\mathrm{pG}+$ host 9 and were the result of integration of the $\Omega \mathrm{Km} 2$ element into the $f b p$ gene (data not shown). One of these $S$. equi fbp:: $\Omega \mathrm{Km} 2$ mutants was selected for further study.

The stability of the $\Omega \mathrm{Km} 2$ fragment in $S$. equi fbp:: $\Omega \mathrm{Km} 2$ was determined after growth of $S$. equi $f b p:: \Omega \mathrm{Km} 2$ for about 40 generations in the absence of antibiotic selection, followed by plating onto THYE agar. The resultant colonies were then replica-plated onto agar containing $\mathrm{Km}$. All 600 colonies screened retained the $\mathrm{Km}^{\mathrm{r}}$ phenotype. Southern hybridization experiments of restricted genomic DNA from eight randomly selected $\mathrm{Km}^{\mathrm{r}}$ colonies showed that all retained the $\Omega \mathrm{Km} 2$ fragment.

To construct a complemented derivative of $S$. equi $f b p:: \Omega \mathrm{Km} 2$, a DNA fragment encompassing the entire $f b p$ gene together with $323 \mathrm{bp}$ of upstream and $136 \mathrm{bp}$ of downstream sequence was amplified using primers F1 and R3, and $S$. equi genomic DNA as a template. Amplification conditions consisted of 30 cycles of denaturation at $95^{\circ} \mathrm{C}$ for $1 \mathrm{~min}$, annealing at $60^{\circ} \mathrm{C}$ for $30 \mathrm{~s}$ and extension at $72^{\circ} \mathrm{C}$ for $4 \mathrm{~min}$, followed by a final extension at $72^{\circ} \mathrm{C}$ for $5 \mathrm{~min}$. The gel-purified product was cleaved with EcoRI and BamHI and cloned into pVA838 cleaved with EcoRI and BamHI, to generate pFBP4. pFBP4 was transformed into $S$. equi $f b p:: \Omega \mathrm{Km} 2$ by electroporation and complemented derivatives possessing a $\mathrm{Km}^{\mathrm{r}} \mathrm{Em}^{\mathrm{r}}$ phenotype were selected. 
Phagocytosis assay. Actively growing cultures of $S$. equi derivatives $\left(\mathrm{OD}_{600} \sim 0 \cdot 14\right)$ were diluted in THYE broth to approximately $1000-3000$ c.f.u. $\mathrm{ml}^{-1}$. Aliquots $(100 \mu \mathrm{l})$ were added to $800 \mu \mathrm{l}$ of either heparinized horse blood or plasma (from horses with no history of strangles) and the suspensions were incubated at $37^{\circ} \mathrm{C}$ for $3 \mathrm{~h}$, with end-over-end rotation. One hundred microlitre aliquots of the resultant suspensions were then plated onto blood agar and incubated at $37^{\circ} \mathrm{C}$ to determine viable counts, as described by Lancefield (1962).

Mouse challenge experiments. All animal experiments were performed in compliance with EC directive 86/609/EC as implemented in Ireland under Statutory Instrument 17/94. Groups of Laca mice (12 weeks old) were challenged by intraperitoneal (i.p.) injection of $200 \mu \mathrm{l}$ vols PBS containing either $S$. equi TW or $S$. equi fbp:: $\Omega \mathrm{Km} 2$. Mice were monitored for $30 \mathrm{~d}$ post challenge and, for humane reasons, were killed if considered terminally ill with body temperatures below $32{ }^{\circ} \mathrm{C}$. Survival times among the challenge groups were analysed statistically using the Mann-Whitney U-test.

Isolation of bacterial cell envelopes and purification of FgBP and recombinant FgBP truncates. Bacterial cell envelopes were isolated from stationary-phase $S$. equi cells, using a method based on French pressure cell lysis, as described previously (Meehan et al., 1998). Native (wild-type) FgBP was purified from mutanolysin extracts of $S$. equi envelopes using horse Fg affinity chromatography, as previously described by Meehan et al. (1998). The construction of recombinant plasmids expressing different affinity-tagged $\mathrm{FgBP}$ truncates (FgBP1-17, FgBP $\left[\mathrm{A}^{-}\right], \mathrm{FgBP}\left[\mathrm{B}^{-}\right]$and $\mathrm{FgBP}\left[\mathrm{A}^{-} \mathrm{B}^{-}\right]$) has been described in detail elsewhere. Briefly, this involved ligation of appropriate PCR-amplified $f b p$ fragments into the pQE30

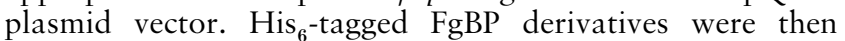
purified from the soluble fractions of transformed E. coli XL1 Blue lysates by metal-chelate affinity chromatography in the presence of protease inhibitors (Meehan et al., 1998, 2000a, b; see Fig. 1a).

Biochemical procedures. SDS-PAGE was performed using both $7.5 \%$ and $12.5 \%(\mathrm{w} / \mathrm{v})$ polyacrylamide separating gels and a $4.5 \%(\mathrm{w} / \mathrm{v})$ polyacrylamide stacking gel, as described by Laemmli (1970). Samples were routinely heated for $3 \mathrm{~min}$ at $100{ }^{\circ} \mathrm{C}$ in sample buffer (Laemmli, 1970) prior to electrophoresis. Proteins were detected by staining with Coomassie brilliant blue. Molecular masses were determined from the relative mobilities of 15 standard molecular mass marker proteins (BenchMark protein ladder; Gibco-BRL). Protein concentrations of purified FgBP truncates and of cell envelope preparations of $S$. equi strains were estimated by a modification (Dulley \& Grieve, 1975) of the Lowry method, using BSA as a standard. The protein concentrations of $\operatorname{IgG}$ solutions were based on details provided by the suppliers.

Immunochemical and affinity procedures. Test tube precipitation experiments were performed using a modification of the immunoprecipitation technique described by Doherty et al. (1986). Purified IgGs $(100 \mu \mathrm{g})$, in $50 \mathrm{mM}$ sodium phosphate ( $\mathrm{pH} 7 \cdot 4$ ) containing $0 \cdot 1 \mathrm{M} \mathrm{NaCl}$, were preincubated for $1 \mathrm{~h}$ at $25^{\circ} \mathrm{C}$ with Complete protease inhibitor cocktail (Roche) and then centrifuged $\left(13000 \mathrm{~g}, 15 \mathrm{~min}, 20^{\circ} \mathrm{C}\right)$. Purified FgBP truncate $(20 \mu \mathrm{g})$ and Triton X-100 (final concn $2 \%, \mathrm{v} / \mathrm{v}$ ) were added to the cleared supernatant, and the solutions were mixed and incubated for $4 \mathrm{~h}$ at $25^{\circ} \mathrm{C}$. The resultant affinity precipitates were harvested by centrifugation $(13000 \mathrm{~g}$, $15 \mathrm{~min}, 20^{\circ} \mathrm{C}$ ), washed twice in $200 \mu \mathrm{l} 0 \cdot 1 \mathrm{M} \mathrm{NaCl}$ containing $0.5 \%(\mathrm{v} / \mathrm{v})$ Triton X-100, and finally resuspended in Laemmli sample buffer with and without 2-mercaptoethanol (Laemmli, 1970). Affinity diffusion assays were conducted as described previously (Meehan et al., 1998).
Western immunoblotting was done as described by Caffrey et al. (1988) using the following reagents: $5 \%(\mathrm{w} / \mathrm{v})$ dried skimmed milk as blocking reagent; mouse anti-recombinant FgBP1 (1:30000 dilution) as primary antibody; and horse radish peroxidase (HRP)-labelled affinity-purified goat antimouse IgG as localizing antibody. Fg-affinity blotting using HRP-labelled horse Fg in 2\% (w/v) dried skimmed milk was performed as described previously (Meehan et al., 1998, 2000a). For IgG-affinity blotting, nitrocellulose blots were blocked with a solution of $2.5 \%(\mathrm{w} / \mathrm{v})$ dried skimmed milk followed by incubation, as appropriate, with unlabelled horse IgG-Fab, unlabelled or HRP-labelled horse IgG-Fc, HRPlabelled Fc of human or rabbit origin, or HRP labelled Fab fragments of either human or rabbit origin $\left(2-10 \mu \mathrm{g} \mathrm{ml}^{-1}\right)$. Where appropriate HRP-labelled affinity-purified goat antihorse $\operatorname{IgG}(\mathrm{H}+\mathrm{L})$ was used as localizing antibody (Meehan et al., 1998). For FgBP1-affinity dot blot experiments, IgGs were probed with HRP-labelled FgBP1 $\left(10 \mu \mathrm{g} \mathrm{ml}^{-1}\right)$. In whole-cell dot blots, $S$. equi suspensions $\left(\mathrm{OD}_{600} 0 \cdot 4\right)$ were subjected to doubling dilutions and $150 \mu \mathrm{l}$ aliquots were transferred onto nitrocellulose using the Bio-Dot apparatus (Bio-Rad). Dried blots were then blocked and developed as described above for Western immunoblotting or equine $\mathrm{Fg} / \mathrm{IgG}$ affinity electroblots. All peroxidase labelled probes were detected using 4chloro-1-naphthol as developing reagent (Meehan et al., 1998). For immunofluorescence microscopy (Henderson et al., 1997), glutaraldehyde-fixed bacterial cells were probed with mouse anti-FgBP1 antiserum (1:400 dilution) followed by FITCconjugated goat anti-mouse immunoglobulins. All experimentation involving Western and dot immunoblotting, immunoprecipitation and immunofluorescence microscopy was repeated two to four times to ensure reproducibility, and representative data are shown in Figs 2-5.

It is appropriate to stress that the antibody-based detection systems for FgBP described above (viz. Western immunoblotting and immunofluorescence microscopy) utilized, as primary and secondary probes, antibodies from animal species (mouse and goat, respectively) which failed to show non-immune reactions with FgBP.

Immunochemical and affinity reagents. Bovine $\operatorname{Ig} G$ was from Chemicon. All other purified IgGs, together with horse Fg and HRP- and FITC-conjugated affinity-purified goat anti-mouse immunoglobulins (Fab-specific), were from Sigma. Goat antihorse IgG $(\mathrm{H}+\mathrm{L})$ was obtained from ICN. Unlabelled horse $\mathrm{IgG}-\mathrm{Fc} / \mathrm{Fab}$ and HRP-labelled human and rabbit IgG-Fc/Fab fragments were obtained from Jackson ImmunoResearch Laboratories. Horse Fg, horse IgG-Fc and FgBP1 were labelled with HRP, as previously described (Meehan et al., 1998). Mouse anti-FgBP1 was generated by immunizing mice subcutaneously on days 0 and 28 with $50 \mu \mathrm{g}$ purified FgBP1 emulsified in $200 \mu \mathrm{l} \mathrm{MPL}+\mathrm{S}$-TDCM Ribi adjuvant (active ingredients monophosphoryl lipid A and trehalose dimycolate; RIBI Immunochem Research). On day 35, mice were exsanguinated and serum was obtained.

\section{RESULTS}

\section{FgBP binds IgG}

Agar gel-diffusion and test tube precipitation experiments performed by incubating recombinant FgBP1 or FgBP12 (which lacks the 19 N-terminal residues critical for Fg binding; Fig. 1a) with purified IgGs from different animal species clearly showed that FgBP is capable of forming insoluble complexes with horse, human, rabbit, 
(a)

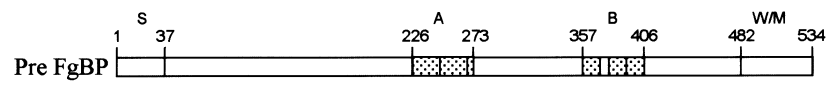

N/C

$\mathrm{FgBP}$

FgBP2

$\mathrm{FgBP} 3$

FgBP4

FgBP12

$\mathrm{FgBP} 13$

FgBP14

FgBP15

FgBP16

FgBP17

FgBP $\left[A^{-}\right]$

$\mathrm{FgBP}\left[\mathrm{B}^{-}\right]$

FgBP $\left[\mathrm{A}^{-} \mathrm{B}^{-}\right]$
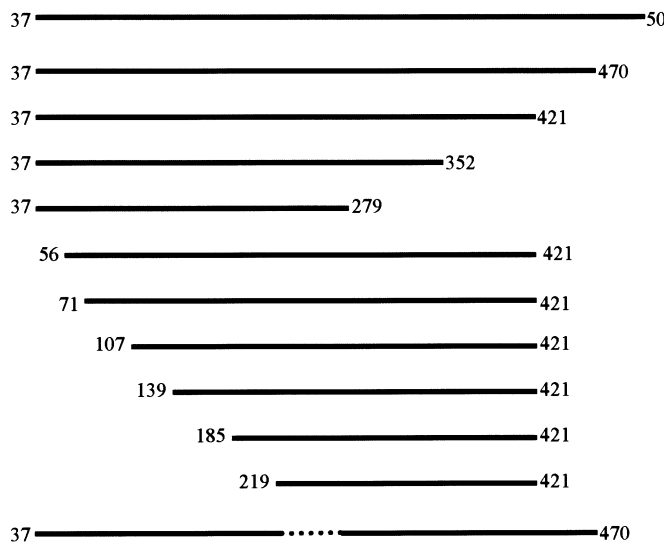

37

37
Fg binding

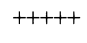

$+++++$

$++++$

$++$

$-$

$-$

$-$

$-$

$-$

$-$

$++++$

$++++$

$++++$

(b)

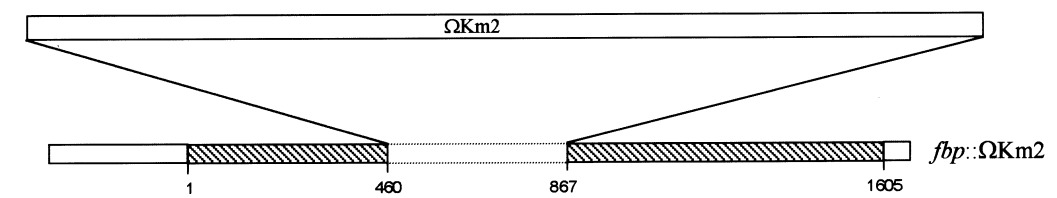

Fig. 1. Schematic representation of (a) FgBP derivatives and (b) the fbp:: $\Omega \mathrm{Km} 2$ DNA fragment used to construct $S$. equi $\mathrm{fbp}$ mutants. (a) The respective amino acid positions of the signal sequence (S), the $A$ and $B$ repeats and the cell wall/membranespanning domain (W/M) are shown in the structure of pre-FgBP. Below the primary structure of $\mathrm{FgBP}$ are scaled representations of the mature (wall-associated) FgBP (N/C-) and of the principal recombinant FgBP truncates used in this study, together with their Fg-binding abilities. Fg-binding ability equivalent to, or half that of wild-type is indicted by +++++ . Four- to eightfold, 16-fold, 32-fold, 64-fold and $\geqslant 128$-fold reductions in Fg-binding potential are indicated by,,,++++++++++ and - , respectively (Meehan et al., 2000a, b). (b) The position (in bp) of the $\Omega \mathrm{Km} 2$ element in relation to the $f b p$ coding sequence (hatched boxes) and flanking sequence (open boxes) is indicated. pig and cat $\operatorname{IgG}$, but not with IgG from mouse, rat, goat, sheep, cow or chicken (see Fig. $2 \mathrm{a}, \mathrm{b}$ ). These results were confirmed in affinity dot blotting experiments in which the various IgGs were probed with HRP-conjugated FgBP1 (data not shown). Since $S$. equi does not cause natural infection in animal species other than the Equidae, the results strongly suggest that FgBP is capable of binding $\operatorname{IgG}$ via a non-immune mechanism. However, a cautionary note has to be struck in relation to (commercial) horse IgG because of the uncertainties regarding the medical history of donor animals (i.e. whether they had a history of strangles).

Most other IgG-binding proteins, such as protein A from Staphylococcus aureus, protein H from Streptococcus pyogenes, and protein $\mathrm{G}$ from group $\mathrm{C}$ and $\mathrm{G}$ streptococci, are known to bind to the Fc region of IgG (Frick et al., 1992). To ascertain whether FgBP binds equine IgG by a similar non-immune mechanism, Western blots were performed using FgBP1 probed with either purified Fab or Fc fragments of horse/human/ rabbit IgG. The results showed that FgBP1 bound strongly to Fc fragments of equine, human and rabbit origin. In contrast, FgBP1 showed only faint reactions with equine Fab fragments and showed no detectable binding to either human or rabbit Fab fragments (Fig. 2c). These results were confirmed using affinity dot blots and ELISA tests (data not shown). Whether the faint reaction observed between equine IgG-Fab and FgBP1 is a consequence of immune or non-immune binding remains to be determined.

\section{Localization of the IgG-binding domain}

To localize the equine IgG-Fc binding domain within FgBP, use was made of a panel of 20 recombinant FgBP proteins containing defined N-terminal, C-terminal and internal deletions of sequence (Meehan et al., 2000a, b; Fig. 1a). Initial Western IgG-affinity blotting experiments showed that FgBP3 and FgBP4 bound equine IgG-Fc weakly or not at all and that the native protein and remaining truncates (Fig. 1a) all bound detectable levels of equine IgG-Fc (data not shown). In order to place these observations on a more quantitative basis and to directly relate $\mathrm{IgG}-\mathrm{Fc}$ binding with comparable Fg-affinity experiments (Meehan et al., 2000a, b), IgGaffinity dot blots were performed using undenatured FgBPs (Fig. 3). These semi-quantitative experiments confirmed the general trend observed during Western affinity blotting and revealed the following in the absence of SDS: (a) wild-type FgBP, FgBP1 (which lacks the wall/membrane anchor domain), FgBP2 (missing 113 amino acids from its C-terminus), FgBP12-13 (missing 19 and 34 residues, respectively, from the $\mathrm{N}$ terminus) and $\mathrm{FgBP}\left[\mathrm{A}^{-}\right], \operatorname{FgBP}\left[\mathrm{B}^{-}\right]$and $\mathrm{FgBP}\left[\mathrm{A}^{-} \mathrm{B}^{-}\right]$all bound similar levels of equine IgG-Fc to a first approximation; (b) FgBP3 (missing 182 amino acids from 


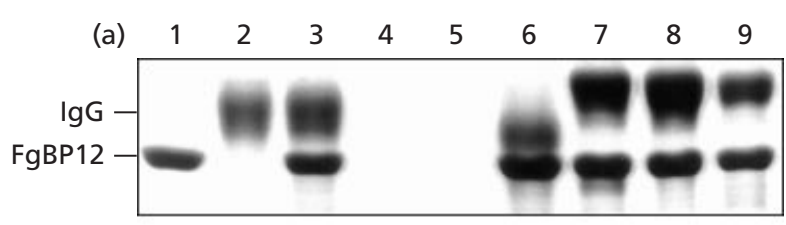

(b)

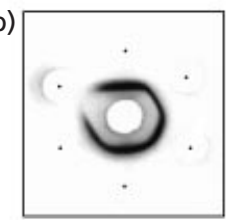

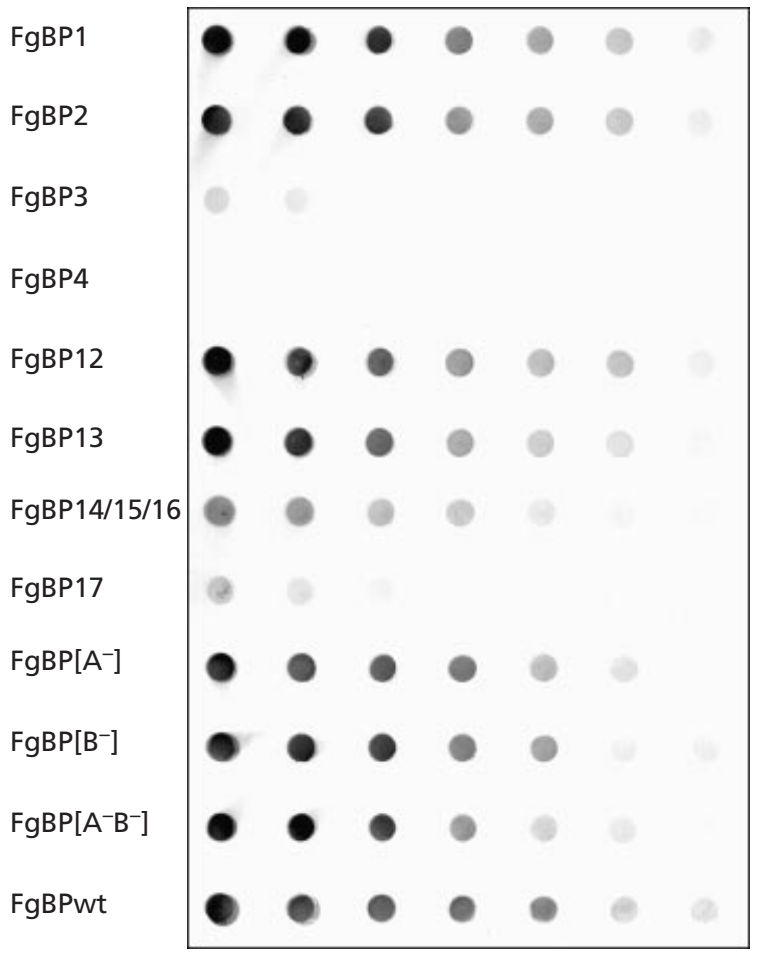

Fig. 3. Equine IgG-Fc-affinity dot blot analysis of undenatured FgBP truncates. The first well in each row of doubling dilutions contains 60 pmol truncate. Sample identity is indicated at the side of the blot with FgBPwt representing wild-type FgBP. Samples were probed with HRP-labelled equine IgG-Fc. FgBPs 14-16 gave identical profiles.

\section{Construction and characterization of $S$. equi fbp:: $\Omega \mathrm{Km} 2$}

Insertional inactivation of the $f b p$ gene was accomplished by replacement of the central $406 \mathrm{bp}$ with the $\Omega K m 2$ element (Perez-Casal et al., 1991; Prentki \& Krisch, 1984; Methods section and Fig. 1b). The $\Omega$ interposon is stably maintained in the chromosome of $S$. equi in the absence of selective pressure and contains strong terminators of transcription and translation. Theoretically, this construct could secrete a $12 \cdot 9 \mathrm{kDa}$ FgBP truncate lacking the C-terminal three-quarters of the native protein. However, several lines of evidence confirm that $S$. equi fbp:: $\Omega \mathrm{Km} 2$ no longer expresses any $\mathrm{FgBP}$ and that, under laboratory conditions, $\mathrm{FgBP}$ is likely to be the major Fg-binding protein expressed by wild-type S. equi. Firstly, SDS-PAGE and Western immuno/affinity blot analyses of mutanolysin-extracted bacterial cell envelopes showed that wild-type $S$. equi, but not $S$. equi $f b p:: \Omega \mathrm{Km} 2$, possessed the mature wallassociated $220 \mathrm{kDa} F \mathrm{FBP}$ which reacted with specific antiserum to FgBP and bound Fg. Secondly, no crossreacting $\mathrm{FgBP}$ polypeptides or any Fg-binding protein could be detected in the envelopes of the $f b p$ mutant strain (Fig. 4) or in the soluble cytoplasmic extracts and culture supernatants of either the wild-type or an isogenic mutant (data not shown). Finally and im- 


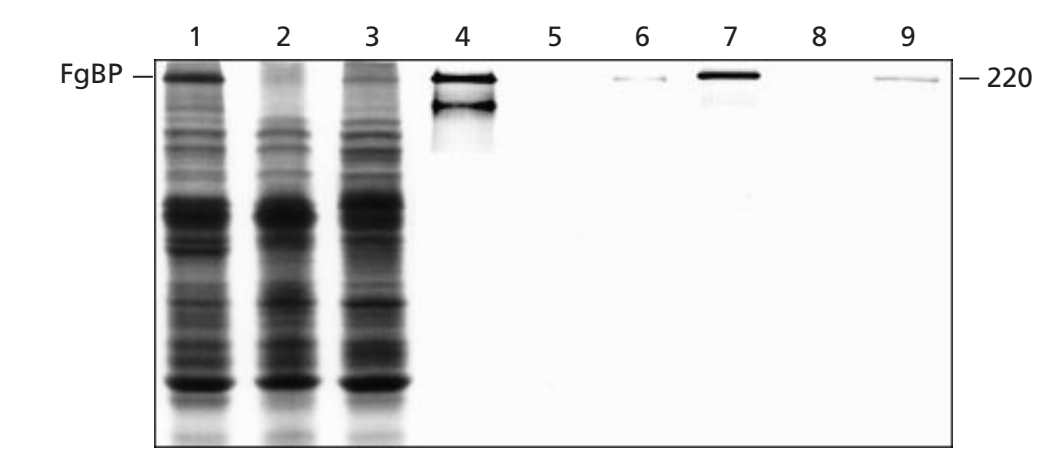

(a)
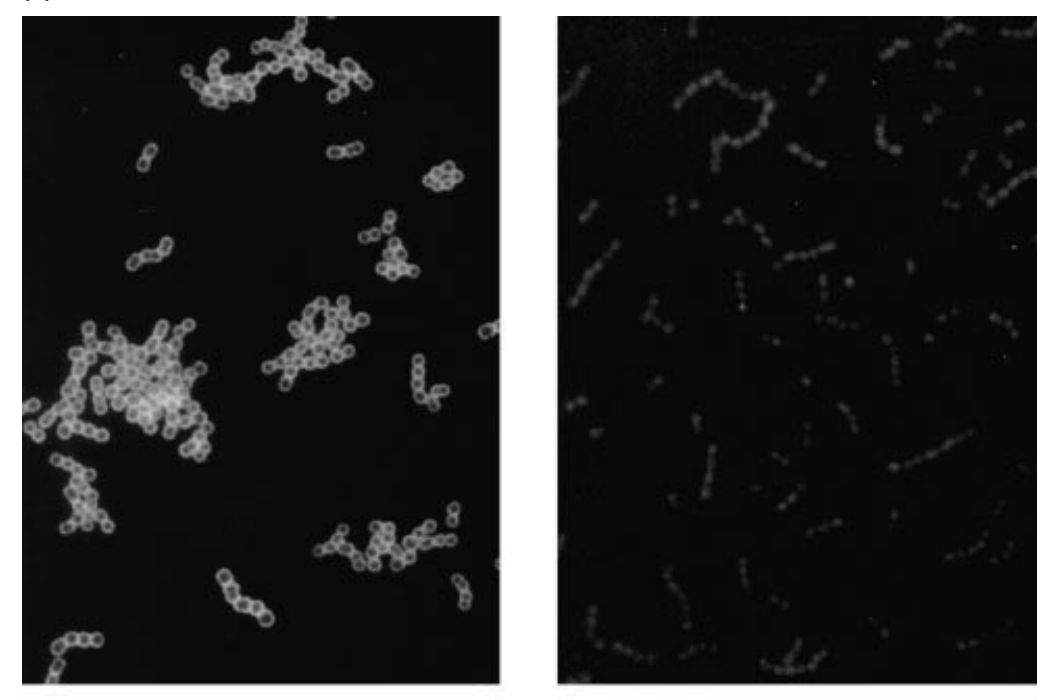

(b)

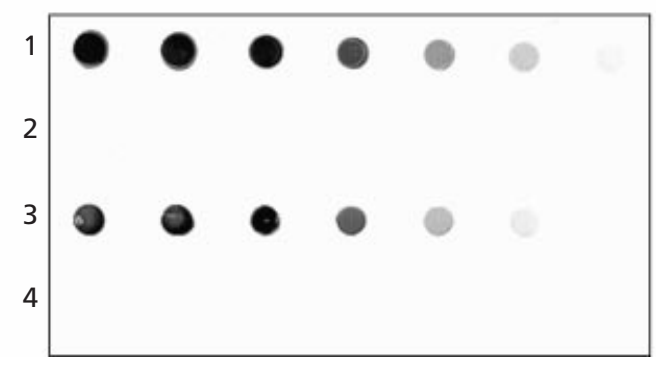

(c)

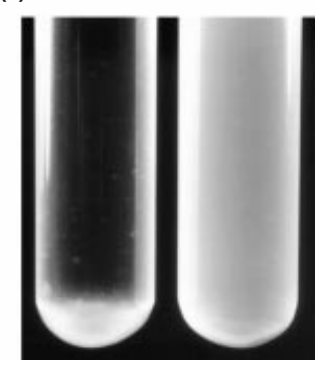

Fig. 4. SDS-PAGE, Western immunoblotting and Fg-affinity blot analysis of mutanolysin-extracted $S$. equi cell envelopes. Mutanolysin-extracted bacterial cell envelopes $(25 \mu \mathrm{g}$ protein) of $S$. equi (lanes 1,4 and 7), S. equi fbp:: $\Omega \mathrm{Km} 2$ (lanes 2, 5 and $8)$ and the complemented derivative $S$. equi fbp:: $\Omega \mathrm{Km} 2$ (pFBP4) (lanes 3, 6 and 9) were analysed by SDS-PAGE using $12.5 \%(\mathrm{w} / \mathrm{v})$ polyacrylamide separating gels. Lanes 1-3 were stained with Coomassie brilliant blue. Lanes 4-9 were electrotransferred onto nitrocellulose and probed with mouse antirecombinant FgBP1 (lanes 4-6) or HRPconjugated horse $\mathrm{Fg}$ (lanes 7-9). The position and apparent molecular mass (in $\mathrm{kDa}$ ) of FgBP are indicated.

Fig. 5. Analysis of $S$. equi and $S$. equi fbp:: $\Omega \mathrm{Km} 2$ by immunofluorescence microscopy, affinity dot blotting and test tube autoaggregation. (a) Immunofluorescent photomicrographs of exponentially growing cultures of $S$. equi (left) and $S$. equi fbp:: $\Omega \mathrm{Km} 2$ (right). Cells were probed with mouse anti-recombinant FgBP1 followed by fluorescein-labelled anti-mouse immunoglobulin. Note that all of the $S$. equi cells, but none of the $S$. equi fbp:: $\Omega \mathrm{Km} 2$ cells, react with the specific anti-FgBP1 antiserum and that the wild-type, but not the mutant, shows a tendency to clump. (b) Fg-affinity and equine IgG-Fc-affinity dot blots of doubling dilutions of whole cells of $S$. equi (rows 1 and 3 ) and $S$. equi fbp:: $\Omega \mathrm{Km} 2$ (rows 2 and 4). Bacterial cells were probed directly with HRP-labelled horse $\mathrm{Fg}$ (rows 1 and 2) or HRP-labelled equine IgG-Fc (rows 3 and 4). (c) S. equi (left) and $S$. equi fbp:: $\Omega \mathrm{Km} 2$ (right) were grown overnight to stationary phase at $37^{\circ} \mathrm{C}$, resuspended and allowed to settle for $2 \mathrm{~h}$ at room temperature.

portantly, immunofluorescence microscopy and wholecell dot blot analysis performed with specific anti-FgBP1 serum, horse Fg or horse IgG-Fc revealed that $S$. equi $f b p:: \Omega \mathrm{Km} 2$ cells, in contrast to those of the wild-type, no longer express FgBP on their cell surface and do not bind detectable levels of either Fg or IgG-Fc (Fig. 5a, b). It should also be noted that both $S$. equi and its $f b p:: \Omega \mathrm{Km} 2$ derivative were encapsulated and grew at the same rate in broth culture (data not shown). However, a characteristic feature of the $f b p$ mutant was its failure to autoaggregate in liquid media during stationary phase in a manner observed for wild-type cells (Fig. 5c). This phenomenon was also evident but to a less dramatic extent in exponential phase (compare Fig. 5a left and right panels).

Analogous experimentation conducted with the complemented derivative $S$. equi fbp:: $\Omega \mathrm{Km} 2(\mathrm{pFBP} 4)$ revealed that it expressed mature functional $\mathrm{FgBP}$ as anticipated, but at considerably lower levels than the wild-type strain (Fig. 4; lanes 3, 6 and 9). This was confirmed by immunofluorescence microscopy, wholecell dot blots and settling experiments (data not shown). The reason for the low expression is unclear, but was a 
Table 2. Survival of $S$. equi and $S$. equi fbp:: $\Omega \mathrm{Km} 2$ in horse blood

Assays were performed in triplicate and are representative of experiments performed on four other occasions.

\begin{tabular}{|c|c|c|c|}
\hline \multirow[t]{2}{*}{ Bacterial strain* } & \multirow{2}{*}{$\begin{array}{l}\text { Initial inoculum } \\
\text { (c.f.u. } \mathrm{ml}^{-1} \text { ) }\end{array}$} & \multicolumn{2}{|c|}{ Final count in: } \\
\hline & & Whole blood (c.f.u. ml $\left.{ }^{-1}\right)^{*}$ & Plasma (c.f.u. $\left.\mathrm{ml}^{-1}\right)^{*}$ \\
\hline \multicolumn{4}{|l|}{ S. equi } \\
\hline Donor 1 & $1 \cdot 43 \pm 0 \cdot 28 \times 10^{2}$ & $3 \cdot 20 \pm 0 \cdot 67 \times 10^{3}$ & $2 \cdot 58 \pm 0 \cdot 72 \times 10^{3}$ \\
\hline Donor 2 & $1.42 \pm 0.08 \times 10^{2}$ & $3.33 \pm 0 \cdot 26 \times 10^{3}$ & $1 \cdot 82 \pm 0.48 \times 10^{3}$ \\
\hline \multicolumn{4}{|c|}{ S. equi fbp:: $\Omega \mathrm{Km} 2$} \\
\hline Donor 1 & $2 \cdot 35 \pm 0 \cdot 33 \times 10^{2}$ & 0 & $3 \cdot 16 \pm 0 \cdot 56 \times 10^{3}$ \\
\hline Donor 2 & $1.97 \pm 0 \cdot 17 \times 10^{2}$ & 0 & $1 \cdot 35 \pm 0 \cdot 22 \times 10^{3}$ \\
\hline
\end{tabular}

*Donor 1 and 2 indicates the identity of the horse from which blood was obtained in the experiment.

consistent feature in attempts to create such constructs. pVA838 does not appear to affect parental levels of FgBP, since $S$. equi TW(pVA838) expressed wild-type levels of the protein as determined by immunofluorescence microscopy and whole-cell dot blot analysis (data not shown). Furthermore, the complemented mutant harboured replicating recombinant pVA838 with full length $f b p$ as evidenced by: (a) Southern blot analysis of restriction enzyme digested-genomic DNA of $S$. equi $f b p:: \Omega \mathrm{Km} 2(\mathrm{pFBP} 4)$ using pVA838- and $f b p$ specific probes; (b) PCR analysis of genomic DNA of $S$. equi fbp:: $\Omega \mathrm{Km} 2(\mathrm{pFBP} 4)$; (c) restriction enzyme digestion analysis of pFBP4 purified from $S$. equi $f b p:: \Omega \mathrm{Km} 2(\mathrm{pFBP} 4)$; and (d) retention of appropriate antibiotic resistance markers. Moreover, there was no evidence of any recombination between recombinant pVA838 and the chromosomal copy of $f b p$ (data not shown). Others in the field have also experienced the problem of poor expression of surface proteins from complemented streptococcal derivatives (Kihlberg et al., 1999).

\section{FgBP is antiphagocytic}

To assess whether FgBP plays a role in resistance of $S$. equi to phagocytosis, the ability of wild-type S. equi TW to survive and grow in non-immune horse blood was compared with that of its isogenic $f b p:: \Omega \mathrm{Km} 2$ derivative (Table 2). The experiment was conducted using blood from two different donor horses that had no history of strangles. As expected both strains grew well in horse plasma. In contrast, only wild-type $S$. equi survived and grew (equally well) in whole blood. The $f b p:: \Omega \mathrm{Km} 2$ derivative lacking FgBP was killed. As anticipated (Boschwitz \& Timoney, 1994b; Timoney et al., 1997), the survival of wild-type $S$. equi was reduced substantially (9- to 45-fold) following the addition of (opsonizing) rabbit anti-FgBP antibodies (data not shown). From this it can be concluded that FgBP plays an important role in resistance of $S$. equi to killing by phagocytes (and/or other blood factors) in the absence of specific antibody.

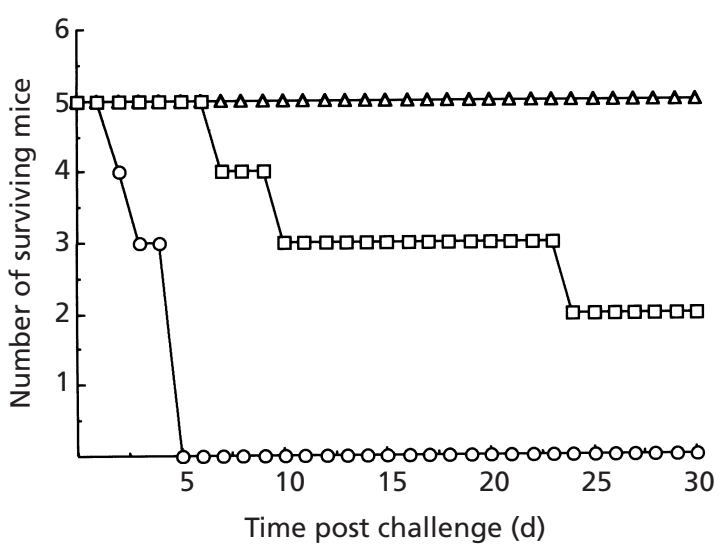

Fig. 6. Virulence of $S$. equi TW and $S$. equi TW fbp:: $\Omega \mathrm{Km} 2$ in mice. Groups of five mice were challenged (i.p.) with $3.3 \times 10^{5}$ c.f.u. S. equi TW $(\bigcirc)$, or with $2.5 \times 10^{5}$ c.f.u. $(\triangle), 2.5 \times 10^{6}$ c.f.u. $(\triangle)$ or, $2.5 \times 10^{7}$ c.f.u. ( $\left.\square\right)$ S. equi TW fbp:: $\Omega \mathrm{Km} 2$. The response of mice to challenge with $2.5 \times 10^{5}$ and $2.5 \times 10^{6}$ c.f.u. $S$. equi TW $f b p:: \Omega K m 2$ was identical. The level of significance between the test (S. equi TW fbp:: $\Omega \mathrm{Km} 2$ ) and control (S. equi TW) challenge groups was $P \leqslant 0.01$.

\section{FgBP contributes to virulence in mice}

It has been previously shown that $S$. equi is virulent in mice and that vaccination with purified FgBP can protect against i.p. infection (Meehan et al., 1998). In order to determine whether FgBP plays a role in virulence, the ability of $S$. equi to cause lethal infection of mice was compared with that of the $f b p$ knockout mutant (S. equi $f b p:: \Omega \mathrm{Km} 2$ ). The results of these experiments (Fig. 6) show clearly that the $f b p$ mutant is considerably more attenuated than wild-type $S$. equi. Thus, all mice challenged with up to $2.5 \times 10^{6}$ c.f.u. of $S$. equi $f b p:: \Omega \mathrm{Km} 2$ remained healthy and survived for over 30 $\mathrm{d}$, whereas mice challenged with a $7 \cdot 6$-fold lower dose of virulent $S$. equi all died within $5 \mathrm{~d}$. Raising the i.p. challenge dose to $2.5 \times 10^{7}$ c.f.u. of $S$. equi fbp:: $\Omega \mathrm{Km} 2$ resulted in $60 \%$ mortality with an extended time to death (Fig. 6). 


\section{DISCUSSION}

One of the principal observations of this study is that FgBP of $S$. equi binds IgG as well as Fg, and does so by a non-immune mechanism involving the $\mathrm{Fc}$ aspect of IgG. FgBP somewhat resembles the Mrp proteins of group A streptococci in its ligand-binding properties (Navarre \& Schneewind, 1999), although FgBP appears to lack the pronounced glutamate/glutamine-rich EQ domain observed for Mrp (and class II Emm) proteins (Pack et al., 1996). FgBP also shows a rather unique profile of IgG binding compared to other IgG binding proteins, showing strong affinity for horse, human, rabbit, pig and cat IgG, but no observable binding to rat, mouse, goat, sheep, bovine and chicken IgG (Akesson et al., 1994; Björck \& Kronvall, 1984; Gomi et al., 1990; Jonsson et al., 1995; Lindmark et al., 1983). Preliminary competition experiments confirm that FgBP probably binds to the same region $\left(\mathrm{C}_{\gamma} 2-\mathrm{C}_{\gamma} 3\right.$ interface) of IgG-Fc as other IgG-binding proteins, such as protein $A$, protein $G$ and protein $H$ (data not shown).

The binding of $\mathrm{Fg}$ and $\mathrm{IgG}$ to FgBP clearly requires distinct structural features. Binding of $\mathrm{Fg}$ is critically dependent on the N-terminal 19 aa and additionally requires a significant stretch of (stabilizing) downstream coiled-coil structure (Meehan et al., 2000a, b). In contrast, IgG-Fc binding does not appear to require residues at the immediate $\mathrm{N}$-terminus, but instead is dependent on a sizeable central domain of FgBP which encompasses both the $\mathrm{A}$ and $\mathrm{B}$ repeat regions. However, in common with the situation for $\mathrm{Fg}$, it is evident that neither the A nor B repeats regions are essential for IgGFc binding. In other IgG-binding proteins, the actual location of and residues involved in $\operatorname{IgG}$ binding varies. Thus, IgG binding is located closer to the N-terminus in the case of protein $\mathrm{H}$ and to the $\mathrm{C}$-terminus for protein G. Furthermore, the IgG-binding domains in protein A and protein $G$ are located in repeat regions, whereas protein $\mathrm{H}$ and $\mathrm{M} 1$ protein appear to have two separate binding sites for IgG which are not present in repeat domains and which appear to bind to different human IgG subsets (Akerström et al., 1987; Frick et al., 1994; Navarre \& Schneewind, 1999; Raeder et al., 1998; Uhlén et al., 1984). Searches of databases for homologies to the amino acid sequence of the putative IgG-binding domain of FgBP reveals significant similarities only with (a) a new protective antigen (Spa) of group A streptococci which shows a curious and remarkable $(98 \%$ ) homology with $S$. equi FgBP over the C-terminal half of the molecule (Dale et al., 1999; GenBank accession no. AF0876813), and (b) the central regions of the Fg/IgG-binding protein DemA from $S$. dysgalactiae. Perhaps significantly, efficient binding of bovine IgG to DemA appears to require this region of the protein (Vasi et al., 2000).

Ligand-binding studies performed with $S$. equi and its $f b p$ insertion mutant provide convincing evidence that FgBP is the dominant surface antigen responsible for the binding of both Fg and IgG by wild-type cells. This confirms and extends previous studies showing that
FgBP in whole cells is accessible to both specific antiserum and Fg and that it is the major Fg-binding protein in mutanolysin-extracted bacterial cell envelopes (Meehan et al., 1998; Timoney et al., 1997). S. equi has the potential to express other surface proteins capable of binding Fg (viz. SzPse; Timoney et al., 1997) or IgG (ZAG; Jonsson et al., 1995; Lindmark et al., 1999). However, these are clearly relatively minor ligandbinding species under the conditions of laboratory growth, since $S$. equi fbp: $: \Omega \mathrm{Km} 2$ binds no detectable Fg and $\mathrm{IgG}-\mathrm{Fc}$.

Previous studies have provided evidence that the $M$ protein of $S$. equi is antiphagocytic (see Introduction). Here, through use of an isogenic $f b p$ derivative, we show conclusively and for the first time that FgBP contributes in a major way to the survival of $S$. equi in whole horse blood. The precise mechanism by which this occurs remains to be elucidated. There is evidence that reduction in $\mathrm{C} 3 \mathrm{~b}$ deposition and Fg binding contribute to the ability of $S$. equi to resist killing by equine neutrophils (Boschwitz \& Timoney, 1994a, b; Chanter et al., 1994), although in our own hands the levels of enhanced survival in the presence of $\mathrm{Fg}$ are marginal (data not shown). The ability of FgBP to bind IgG-Fc suggests another possible mechanism for resistance to phagocytosis. Certainly, for the clinically important (M1) serotype of group A streptococcus it has been convincingly established that the IgG-binding protein $\mathrm{H}$ can block C3 deposition due to inhibition of the classical complement pathway, and that the presence of either protein $\mathrm{H}$ or the $\mathrm{Fg}$-binding $\mathrm{M} 1$ protein on the cell surface is sufficient for survival in human blood (Berge et al., 1997; Kihlberg et al., 1999). In other cases, reduction in $\mathrm{C} 3 \mathrm{~b}$ deposition has been attributed to the ability of $\mathrm{M}$ proteins to bind complement regulators (see Introduction).

Some streptococcal $\mathrm{M}$ proteins can also mediate bacterial autoaggregation, and this property has been shown to be crucial for adherence and for resistance to phagocytosis (Frick et al., 2000). Such a mechanism cannot be ruled out for virulent $S$. equi. Comparative microscopic and sedimentation analysis shows that wild-type $S$. equi routinely grows as large sedimentable aggregates, whereas the $f b p:: \Omega \mathrm{Km} 2$ knockout mutant does not (see Fig. 5; data not shown). FgBP does not possess the conserved 19 amino acid residue (AHP) sequence which has been implicated in the homophilic protein-protein interactions responsible for formation of $S$. pyogenes aggregates (Frick et al., 2000); however, it can form apparent multimers under certain conditions and the B-repeats of FgBP have been heavily implicated in this process (Meehan et al., 2000b).

It is relevant to note that other streptococcal surface components, such as the hyaluronic acid capsule, have also been implicated in resistance to phagocytosis. In the case of $S$. equi, strains expressing lower amounts of capsule seem to be more susceptible to phagocytosis and to cause a less invasive disease than heavily capsulated strains (Anzai et al., 1999b). The virulent strain of $S$. 
equi TW used in the current studies does express capsule under conditions of laboratory growth; however, it is clear from the experimental data that the level of capsule produced is insufficient to prevent efficient phagocytic killing in the absence of both $\mathrm{FgBP}$ and specific antibody.

The M-like protein (FgBP) of S. equi has been recognized for a number of years as a likely virulence determinant. It is structurally and functionally similar to the wellstudied $M$ protein virulence factors of group A streptococci, possesses anti-phagocytic properties (see above), and elicits strong serum and mucosal antibody responses in infected horses. However, direct evidence that FgBP contributes to virulence has been lacking until now. The results of the small animal experiments conducted with $S$. equi and $S$. equi $f b p:: \Omega \mathrm{Km} 2$ provide compelling evidence that this is indeed the case. Supporting evidence that $\mathrm{FgBP}$ is important in $S$. equi infection of the target species comes from a recent study of horses that were outwardly healthy but were shown to be persistent carriers of $S$. equi. Streptococcal isolates from about $25 \%$ of these carriers expressed truncated forms of FgBP (lacking the N-terminal Fg-binding region) and were more sensitive to phagocytosis (Chanter et al., 2000). Clearly, the balance of evidence presented here and elsewhere strongly suggests that the antiphagocytic properties of FgBP contribute to the virulence of $S$. equi. This is not to exclude other possible roles. Certainly, there is a multitude of studies suggesting that Fg-and/or IgG-binding M proteins of group A streptococci are involved in adhesion, invasion and colonization (Cleary \& Retnoningrum, 1994; Dombek et al., 1999; Molinari \& Chhatwal, 1999; Navarre \& Schneewind, 1999). Furthermore, wall-anchored M protein has recently been implicated in the maturation of cysteine proteinase (Collin \& Olsén, 2000). In turn, cysteine proteinase has been shown to release, from the cell surface, biologically active fragments of $M$ protein and protein $\mathrm{H}-\mathrm{IgG}$ complexes (Berge \& Björck, 1995; Berge et al., 1997). It has been suggested that the deposition of the protein $\mathrm{H}-\mathrm{IgG}$ complexes onto body organs may cause localized inflammation and tissue damage, and thus contribute to severe complications of suppurative $S$. pyogenes infection. Interestingly, purpura haemorrhagica, a fatal sequel to strangles, has been proposed to be an immune-complex-mediated disease (Galán \& Timoney, 1985). Clearly the role of FgBP and its IgG-binding properties in complications associated with this disease appear to warrant further investigation. Challenge trials in horses using $S$. equi $f b p:: \Omega \mathrm{Km} 2$ and similar derivatives should also provide a further insight into the role of FgBP and other potential S. equi virulence factors in the disease process (Anzai et al., 1999a, b; Chanter et al., 1999; Flanagan et al., 1998; Harrington et al., 2000; Muhktar \& Timoney, 1988).

\section{ACKNOWLEDGEMENTS}

This work was supported by The National Pharmaceutical Biotechnology Centre, BioResearch Ireland and by a research grant SC/98/266 from Enterprise Ireland. The authors would like to thank personnel at the Irish Equine Center for supplying horse blood from animals with no recorded history of strangles.

\section{REFERENCES}

Åkerström, B., Nielsen, B. \& Björck, L. (1987). Definition of IgGand albumin-binding regions of streptococcal protein G. J Biol Chem 262, 13388-13391.

Åkesson, P., Schmidt, K.-H., Cooney, J. \& Björck, L. (1994). M1 protein and protein $\mathrm{H}$ : IgGFc- and albumin-binding streptococcal surface proteins encoded by adjacent genes. Biochem J 300, 877-886.

Anzai, T., Sheoran, A. S., Kuwamoto, Y., Kondo, T., Wada, R., Inoue, T. \& Timoney, J. F. (1999a). Streptococcus equi but not Streptococcus zooepidemicus produces potent mitogenic responses from equine peripheral blood mononuclear cells. Vet Immunol Immunopathol 67, 235-246.

Anzai, T., Timoney, J. F., Kuwamoto, Y., Fujita, Y., Wada, R. \& Inoue, T. (1999b). In vivo pathogenicity and resistance to phagocytosis of Streptococcus equi strains with different levels of capsule expression. Vet Microbiol 67, 277-286.

Berge, A. \& Björck, L. (1995). Streptococcal cysteine proteinase releases biologically active fragments of streptococcal surface proteins. J Biol Chem 270, 9862-9867.

Berge, A., Kihlberg, B.-M., Sjöholm, A. G. \& Björck, L. (1997). Streptococcal protein $\mathrm{H}$ forms soluble complement-activating complexes with $\operatorname{IgG}$, but inhibits complement activation by IgGcoated targets. J Biol Chem 272, 20774-20781.

Björck, L. \& Kronvall, G. (1984). Purification and some properties of streptococcal protein G, a novel IgG-binding reagent. $J$ Immunol 133, 969-974.

Boschwitz, J. S. \& Timoney, J. F. (1994a). Characterization of the antiphagocytic activity of equine fibrinogen for Streptococcus equi subsp. equi. Microb Pathog 17, 121-129.

Boschwitz, J. S. \& Timoney, J. F. (1994b). Inhibition of C3 deposition on Streptococcus equi subsp. equi by M protein: a mechanism for survival in equine blood. Infect Immun 62, 3515-3520.

Caffrey, P., McVeigh, T. \& Owen, P. (1988). Western immunoblotting. In Immunochemical and Molecular Genetic Analysis of Bacterial Pathogens, pp. 255-266. Edited by P. Owen \& T. J. Foster. Amsterdam: Elsevier.

Caparon, M. G. \& Scott, J. R. (1991). Genetic manipulation of pathogenic streptococci. Methods Enzymol 204, 556-586.

Chanter, N., Collin, N. C. \& Mumford, J. A. (1994). Resistance of Streptococcus equi in vitro to equine polymorphonuclear leucocytes. In Equine Infectious Diseases VII: Proceedings of the Seventh International Conference, Tokyo, Japan, 8th-11th June 1994, pp. 201-210. Edited by H. Nakajima \& W. Plowright. Newmarket: R \& W Publications.

Chanter, N., Ward, C. L., Talbot, N. C., Flanagan, J. A., Binns, M., Houghton, S. B., Smith, K. C. \& Mumford, J. A. (1999). Recombinant hyaluronate associated protein as a protective immunogen against Streptococcus equi and Streptococcus zooepidemicus challenge in mice. Microb Pathog 27, 133-143.

Chanter, N., Talbot, N. C., Newton, J. R., Hewson, D. \& Verheyen, K. (2000). Streptococcus equi with truncated M-proteins isolated from outwardly healthy horses. Microbiology 146, 1361-1369.

Cleary, P. \& Retnoningrum, D. (1994). Group A streptococcal immunoglobulin-binding proteins: adhesins, molecular mimicry or sensory proteins? Trends Microbiol 2, 131-136.

Collin, M. \& Olsén, A. (2000). Generation of a mature streptococcal 
cysteine proteinase is dependent on cell wall-anchored M1 protein. Mol Microbiol 36, 1306-1318.

Dale, J. B., Chiang, E. Y., Liu, S., Courtney, H. S. \& Hasty, D. L. (1999). New protective antigen of group A streptococci. J Clin Investig 103, 1261-1268.

Doherty, H., Yamada, H., Caffrey, P. \& Owen, P. (1986). Identification, immunochemical characterization, and purification of a major lipoprotein antigen associated with the inner (cytoplasmic) membrane of Escherichia coli. J Bacteriol 166, 1072-1082.

Dombek, P. E., Cue, D., Sedgewick, J., Lam, H., Ruschkowski, S., Finlay, B. B. \& Cleary, P. P. (1999). High-frequency intracellular invasion of epithelial cells by serotype $\mathrm{M} 1$ group A streptococci: M1 protein-mediated invasion and cytoskeletal rearrangements. Mol Microbiol 31, 859-870.

Dulley, J. R. \& Grieve, P.A. (1975). A simple technique for eliminating interference by detergents in the Lowry method of protein determination. Anal Biochem 64, 136-141.

Feliciello, I. \& Chinali, G. (1993). A modified alkaline lysis method for the preparation of highly purified plasmid DNA from Escherichia coli. Anal Biochem 212, 394-401.

Flanagan, J., Collin, N., Timoney, J., Mitchell, T., Mumford, J. A. \& Chanter, N. (1998). Characterization of the haemolytic activity of Streptococcus equi. Microb Pathog 24, 211-221.

Frick, I.-M., Wikström, M., Forsén, S., Drakenberg, T., Gomi, H., Sjöbring, U. \& Björck, L. (1992). Convergent evolution among immunoglobulin G-binding bacterial proteins. Proc Natl Acad Sci US A 89, 8532-8536.

Frick, I.-M., Åkesson, P., Cooney, J. \& 7 other authors (1994). Protein $\mathrm{H}$ - a surface protein of Streptococcus pyogenes with separate binding sites for IgG and albumin. Mol Microbiol 12, 143-151.

Frick, I.-M., Mörgelin, M. \& Björck, L. (2000). Virulent aggregates of Streptococcus pyogenes are generated by homophilic proteinprotein interactions. Mol Microbiol 37, 1232-1247.

Galán, J. E. \& Timoney, J. F. (1985). Immune complexes in purpura hemorrhagiaca of the horse contain $\operatorname{IgA}$ and $M$ antigen of Streptococcus equi. J Immunol 135, 3134-3137.

Gomi, H., Hozumi, T., Hattori, S., Tagawa, C., Kishimoto, F. \& Björck, L. (1990). The gene sequence and some properties of protein H. A novel IgG-binding protein. J Immunol 144, 4046-4052.

Harrington, D. J., Greated, J. S., Chanter, N. \& Sutcliffe, I. C. (2000). Identification of lipoprotein homologues of pneumococcal PsaA in the equine pathogens Streptococcus equi and Streptococcus zooepidemicus. Infect Immun 68, 6048-6051.

Henderson, I. R., Meehan, M. \& Owen, P. (1997). Antigen 43, a phase-variable bipartite outer membrane protein, determines colony morphology and autoaggregation in Escherichia coli K-12. FEMS Microbiol Lett 149, 115-120.

Jonsson, H., Lindmark, H. \& Guss, B. (1995). A protein G-related cell surface protein in Streptococcus zooepidemicus. Infect Immun 63, 2968-2975.

Kehoe, M. A. (1994). Cell-wall-associated proteins in Grampositive bacteria. In New Comprehensive Biochemistry, vol. 27, Bacterial Cell Wall, pp. 217-261. Edited by J.-M. Ghuysen \& R. Hakenbeck. Amsterdam: Elsevier.

Kihlberg, B.-M., Collin, M., Olsén, A. \& Björck, L. (1999). Protein $\mathrm{H}$, an antiphagocytic surface protein in Streptococcus pyogenes. Infect Immun 67, 1708-1714.

Laemmli, U. K. (1970). Cleavage of structural proteins during the assembly of the head of bacteriophage T4. Nature 227, 680-685.
Lancefield, R. C. (1962). Current knowledge of type-specific M antigens of group A streptococci. J Immunol 89, 307-313.

Lech, K. \& Brent, R. (1997). Media preparation and bacteriological tools. In Current Protocols in Molecular Biology, pp. 1.1.1-1.1.6. Edited by F. M. Ausubel, R. Brent, R. E. Kingston, D. D. Moore, J. G. Seidman, J. A. Smith \& K. Struhl. New York: Wiley.

Lindmark, H. \& Guss, B. (1999). SFS, a novel fibronectin-binding protein from Streptococcus equi, inhibits the binding between fibronectin and collagen. Infect Immun 67, 2383-2388.

Lindmark, H., Jonsson, P., Engvall, E. \& Guss, B. (1999). Pulsedfield gel electrophoresis and distribution of the genes $z a g$ and $f n z$ in isolates of Streptococcus equi. Res Vet Sci 66, 93-99.

Lindmark, H., Nilsson, M. \& Guss, B. (2001). Comparison of the fibronectin-binding protein FNE from Streptococcus equi subspecies equi with FNZ from S. equi subspecies zooepidemicus reveals a major and conserved difference. Infect Immun 69, 3159-3163.

Lindmark, R., Thoren-Tolling, K. \& Sjoquist, J. (1983). Binding of immunoglobulins to protein $\mathrm{A}$ and immunoglobulin levels in mammalian sera. J Immunol Methods 62, 1-13.

Macrina, F. L., Tobian, J. A., Jones, K. R., Evans, R. P. \& Clewell, D. B. (1982). A cloning vector able to replicate in Escherichia coli and Streptococcus sanguis. Gene 19, 345-353.

Maguin, E., Prévost, H., Ehrlich, S. D. \& Gruss, A. (1996). Efficient insertional mutagenesis in lactococci and other gram-positive bacteria. J Bacteriol 178, 931-935.

Meehan, M., Nowlan, P. \& Owen, P. (1998). Affinity purification and characterization of a fibrinogen-binding protein complex which protects mice against lethal challenge with Streptococcus equi subsp. equi. Microbiology 144, 993-1003.

Meehan, M., Muldowney, D. A., Watkins, N. J. \& Owen, P. (2000a). Localization and characterization of the ligand-binding domain of the fibrinogen-binding protein (FgBP) of Streptococcus equi subsp. equi. Microbiology 146, 1187-1194.

Meehan, M., Muldowney, D. A., O'Meara, F. \& Owen, P. (2000b). Neither the A- nor B-repeat regions of the fibrinogen-binding protein of Streptococcus equi subsp. equi are essential for fibrinogen binding. FEMS Microbiol Lett 190, 317-321.

Molinari, G. \& Chhatwal, G. S. (1999). Streptococcal invasion. Curr Opin Microbiol 2, 56-61.

Muhktar, M. M. \& Timoney, J. F. (1988). Chemotactic response of equine polymorphonuclear leucocytes to Streptococcus equi. Res Vet Sci 45, 225-229.

Navarre, W. W. \& Schneewind, O. (1999). Surface proteins of Gram-positive bacteria and mechanisms of their targeting to the cell wall envelope. Microbiol Mol Biol Rev 63, 174-229.

Pack, T. D., Podbielski, A. \& Boyle, M. P. D. (1996). Identification of an amino acid signature sequence predictive of protein $\mathrm{G}$ inhibitable IgG3-binding activity in group-A streptococcal IgGbinding proteins. Gene 171, 65-70.

Perez-Casal, J., Caparon, M. G. \& Scott, J. R. (1991). Mry, a transacting positive regulator of the $\mathrm{M}$ protein gene of Streptococcus pyogenes with similarity to the receptor proteins of twocomponent regulatory systems. J Bacteriol 173, 2617-2624.

Prentki, P. \& Krisch, H. M. (1984). In vitro insertional mutagenesis with a selectable DNA fragment. Gene 29, 303-313.

Raeder, R., Woischnik, M., Podbielski, A. \& Boyle, M. D. (1998). A secreted streptococcal cysteine protease can cleave a surfaceexpressed M1 protein and alter the immunoglobulin binding properties. Res Microbiol 149, 539-548.

Ringdahl, U., Svensson, H. G., Kotarsky, H., Gustafsson, M., 
Weineisen, M. \& Sjöbring, U. (2000). A role for the fibrinogenbinding regions of streptococcal $\mathrm{M}$ proteins in phagocytosis resistance. Mol Microbiol 37, 1318-1326.

Sambrook, J., Fritsch, E. F. \& Maniatis, T. (1989). Molecular Cloning: a Laboratory Manual, 2nd edn. Cold Spring Harbor, NY: Cold Spring Harbor Laboratory.

Timoney, J. F. (1993). Strangles. Vet Clin North Am Equine Pract 9, 365-374.

Timoney, J. F., Artiushin, S. C. \& Boschwitz, J. S. (1997). Comparison of the sequences and functions of Streptococcus equi Mlike proteins SeM and SzPSe. Infect Immun 65, 3600-3605.

Uhlén, M., Guss, B., Nilsson, B., Gatenbeck, S., Philipson, L. \&
Lindberg, M. (1984). Complete sequence of the staphylococcal gene encoding protein A. A gene evolved through multiple duplications. J Biol Chem 259, 1695-1702.

Vasi, J., Frykberg, L., Carlsson, L. E., Lindberg, M. \& Guss, B. (2000). M-like proteins of Streptococcus dysgalactiae. Infect Immun 68, 294-302.

Yu, C.-E. \& Ferretti, J. J. (1989). Molecular epidemiologic analysis of the type A streptococcal exotoxin (erythrogenic toxin) gene (speA) in clinical Streptococcus pyogenes strains. Infect Immun 57, 3715-3719.

Received 30 May 2001; revised 1 August 2001; accepted 9 August 2001. 